\title{
EJJS Special Collection: Yiddish in Europe
}

Neuberg, Simon. "The First Yiddish Book Printed in Amsterdam: Śefer Mismor Lethode." EJJS 4(1) (2010): 7-21. DOI: 10.1163/187247110X521137. https://brill .com/view/journals/ejjs/4/1/article-p7_3.xml.

Schäfer, Lea. "On the Frontier between Eastern and Western Yiddish: Sources from Burgenland." EJJS 11(2) (2017): 130-147. DoI: 10.1163/1872471X-1112109o. https://brill.com/view/journals/ejjs/11/2/article-p13o_13o.xml.

Cohen, Nathan. "The Love Story of Esterke and Kazimierz, King of PolandNew Perspectives." EJJS 9(2) (2015): 176-209. DoI: 10.1163/1872471X-1234128o. https://brill.com/view/journals/ejjs/9/2/article-p176_5.xml.

Stromberg, David. “Your Papers for a Tourist Visa': A Literary-Biographical Consideration of Isaac Bashevis Singer in Warsaw, 1923-1935." EJJS 15(2) (2021): 256-284. DOI: 10.1163/1872471X-bja10oo7. https://brill.com/view/ journals/ejjs/15/2/article-p256_4.xml.

Gal-Ed, Efrat. "Between Jesus and the Besht." EJJS 4(1) (2010): 115-136. DoI: 10.1163/187247110X521245. https://brill.com/view/journals/ejjs/4/1/article-p115 $-7 . x m l$.

Frankel, Hazel. "Stones in the Landscape: Memory and Postmemory in the Yiddish Poems of David Fram." EJJS 11(2) (2017): 148-173. DOI: 10.1163/1872471X -11121029. https://brill.com/view/journals/ejjs/11/2/article-p148_148.xml.

\section{Introduction}

Yiddish is one of the European languages of a truly transnational nature, historically connecting diasporic Ashkenazi communities. The study of Yiddish, the language, culture, and heritage, therefore, is key to European Jewish Studies. Throughout the years, Yiddish has been one of the strong foci of the European Journal of Jewish Studies (EJJS), and therefore, we have chosen this representative selection of articles on Yiddish to be our first special collection of past EJJS articles, which, thanks to the generosity of our publisher, we are happy to make freely available for a limited period online. This collection will be available online for three months, starting with February 15, 2022.

The next special collection, on Jewish folklore and folk culture, will be posted in the autumn of 2022, and we hope to continue with many more such 
collections in the coming years. Again, we are most grateful that our publisher has enthusiastically embraced this initiative to make the highlights of past EJJS issues available to a wider circle of readers. We hope that it will help draw attention to the most interesting past articles and research trends represented on the pages of our journal.

The seven articles that we have selected for this special collection cover Western and Eastern Europe, and even post-Holocaust South Africa, early modern and modern times, high and popular Yiddish cultures. As such, the collection handsomely represents the width and breath of past EJJS articles on this topic. The first article, by Simon Neuberg, focuses on the early modern period and highlights the first Western Yiddish book printed in Amsterdam, the so-called "Jewish Bookshop of the World." This contribution is located on the crossroads between Yiddish linguistics and Jewish book history. In the second article, Lea Schäfer explores the gradual transition from Western to Eastern Yiddish in the Austrian Burgenland region, using dialectology and phonology to assess the specific nature of the regional variant of the Yiddish that was historically spoken there.

Nathan Cohen demonstrates how German and Polish sources informed nineteenth and twentieth century Yiddish and Hebrew historical novels in the folktale about the love affair between the Polish King Kazimierz the Great and the Jewish girl Esterke. Two of the best-known modern Yiddish authors, Isaac Bashevis Singer and Itzik Manger, are central to the articles by David Stromberg and Efrat Gal-Ed. Both sketch the Yiddish literary scene and contextualize Yiddish literary contributions to the European cultural and physical landscape.

The last contribution deals with the poet David Fram, who moved from Lithuania to South Africa in the twentieth century. Hazel Frankel argues that he reconstructed the lost world of the shtetl in his poems and analyzes them from the perspective of memory studies, invoking the concept of postmemory to study Fram's reimagination of his European past. All in all, these collected articles demonstrate the variety of Yiddish studies in Europe: from Western to Eastern Yiddish, from linguistics to literary analysis, and from the past to the present.

\section{Bart Wallet}

European Journal of Jewish Studies, Editor, Digital Humanities 